\title{
Mutation screening of the RNF8, UBC13 and MMS2 genes in Northern Finnish breast cancer families
}

\author{
Mikko Vuorela, Katri Pylkäs and Robert Winqvist
}

\begin{abstract}
Background: Currently known susceptibility genes such as BRCA1 and BRCA2 explain less than 25\% of familial aggregation of breast cancer, which suggests the involvement of additional susceptibility genes. RNF8, UBC13 and MMS2 are involved in the DNA damage response pathway and play important roles in BRCA1-mediated DNA damage recognition. Based on the evidence that several players in the ubiquitin-mediated BRCA1-dependent DDR seem to contribute to breast cancer predisposition, RNF8, UBC13 and MMS2 were considered plausible candidate genes for susceptibility to breast cancer.
\end{abstract}

Methods: The entire coding region and splice junctions of RNF8, UBC13 and MMS2 genes were screened for mutations in affected index cases from 123 Northern Finnish breast cancer families by using conformation sensitive gel electrophoresis, high resolution melting (HRM) analysis and direct sequencing.

Results: Mutation analysis revealed several changes in RNF8 and UBC13, whereas no aberrations were observed in MMS2. None of the found sequence changes appeared to associate with breast cancer susceptibility.

Conclusions: The present data suggest that mutations in RNF8, UBC13 and MMS2 genes unlikely make any sizeable contribution to breast cancer predisposition in Northern Finland.

\section{Background}

Breast cancer is the most frequent malignancy among women [1], and the presence of a family history is one of the most fundamental risk factors for the disease [2]. Currently known susceptibility genes including $B R C A 1$, BRCA2, ATM, CHEK2, PALB2, RAD51C and BRIP1 explain less than $25 \%$ of familial breast cancer. The rest of the cases could be explained by mutations in mainly moderate and low penetrance cancer susceptibility genes together with environmental factors. Many of the genes already associated with breast cancer susceptibility encode proteins that operate together with BRCA1 and BRCA2 in the DNA damage response pathway (DDR) [3-7]. Other genes with similar functions thus represent good candidates for being new susceptibility genes.

Recent evidence indicates ubiquitin chain formation, recognitionand breakdown at the site of DNA doublestrand breaks (DSB) as an essential component of the DDR [8]. RNF8 is a RING-finger ubiquitin ligase (E3),

\footnotetext{
*Correspondence: robert.winqvist@oulu.fi

Laboratory of Cancer Genetics, Department of Clinical Genetics and Biocenter Oulu, University of Oulu, Oulu University Hospital, P.O. Box 5000, Fl-90014, Oulu, Finland
}

(C) 2011 Vuorela et al; licensee BioMed Central Ltd. This is an Open Access article distributed under the terms of the Creative Commons Attribution License (http://creativecommons.org/licenses/by/2.0), which permits unrestricted use, distribution, and reproduction in any medium, provided the original work is properly cited. ATM/ATR-dependent phoshorylation of the H2AX histone variant [9-11]. Together with its ubiquitin-conjugating enzyme (E2) partner UBC13 it mediates K63linked polyubiquitin conjugation to histones $\mathrm{H} 2 \mathrm{~A}$ and H2AX. The RNF8/UBC13-dependent histone ubiquitylation is then amplified by the RNF168 E3-ligase acting in concert with UBC13 [12]. Ubiquitynated histones are recognized by RAP80 through its ubiquitin interaction motifs (UIMs), which provide an ubiquitin recognition element to target the BRCA1 E3 ligase, Abraxas, MERIT40, BRCC45 and a K63-ubiquitin specific deubiquitinating enzyme BRCC36 to DSBs. Each of these activities is required for appropriate checkpoint and repair responses to ionizing radiation [13-15]. Depletion of RNF8 or UBC13 in vitro leads to inhibition of the recruitment of 53BP1, BRCA1, RAP80 and Abraxas to DSB sites $[9-11,16]$. It has also been demonstrated that the depletion of RNF8 leads to increased ionizing radiation sensitivity and defective G2/M checkpoint [9-11]. In addition, $R n f 8^{-1-}$ mice display increased genomic instability and higher risk for tumorigenesis, proposing that RNF8 is a novel tumor suppressor [17]. 
Besides RNF8, the ubiquitin E2 variant (UEV) MMS2 seems to be essential for certain functions of UBC13. MMS2 forms a complex with UBC13 [18], and this heterodimer formation has been demonstrated to be essential for the DNA damage repair function of UBC13 [19]. Suppression of UBC13 or MMS2 has been shown to increase the sensitivity to DNA damaging agents [19], although the exact role of MMS2 in DDR is still unclear [20].

We have previously reported a potentially deleterious germline variant of RAP8O (del81E) that abrogated ubiquitin binding and DNA damage response in breast cancer cases [21]. Additionally, recent findings of an extensive genome-wide linkage consortium study suggested an association between the rare allele of single nucleotide polymorphism (SNP) rs8170 in MERIT40 and an increased propensity for hormone receptor-negative breast cancer, both in the general population and in BRCA1 mutation carriers [22]. Based on the evidence that several players in the ubiquitin-mediated BRCA1dependent DDR seem to contribute to breast cancer predisposition (summarized in Table 1), we decided to examine the role of RNF8, UBC13 and MMS2 in familial breast cancer by performing a comprehensive mutation screening of these genes in 123 Northern Finnish breast cancer families.

\section{Methods}

\section{Study population}

Affected index cases of 123 breast cancer families from Northern Finland were screened for germline mutations in the RNF8, UBC13 and MMS2 genes. From the studied families, 77 were classified as high-risk ones, defined as follows: 1) three or more cases of breast and/ or ovarian cancer in first or second-degree relatives (median age 49 years, variation $37-80$ years), or 2) two

$\begin{aligned} & \text { Table } \\
& \text { - Key operators in the BRCA1-dependent ubiquitin }\end{aligned}$
\begin{tabular}{lll} 
currently known role in breast cancer predisposition \\
\hline Gene & $\begin{array}{l}\text { Previous studies on the role } \\
\text { in breast cancer predisposition }\end{array}$ & $\begin{array}{l}\text { Disease related } \\
\text { alterations }\end{array}$ \\
\hline RNF8 & Not done & - \\
RNF168 & Not done & - \\
UBC13 & Not done & \\
RAP80 & Mutation screening $[21,27-29]$ & del81E [21] \\
Abraxas & Mutation screening $[27,29]$ & N. I. \\
MERIT40 & Mutation screening $[30]$ & N.I. \\
GRCC45 & Not done & rs8170 [22] \\
BRCC36 & Not done & - \\
\hline
\end{tabular}

${ }^{a}$ Homozygous mutations in this gene have been demonstrate to result in RIDDLE syndrome [12].

GWAS, genome wide association study; N. I., not identified. cases of breast cancer in first- or second-degree relatives, of which at least one with early disease onset (age $\leq 35$ years), bilateral disease or multiple primary tumors. Most of the high-risk families presented three or more cancer cases. The remaining 46 families with moderate disease susceptibility indicated two cases of breast cancer in first- or second-degree relatives. Fourteen of the studied index cases had previously been tested positive for known breast cancer-associated germline mutations in BRCA1 or BRCA2 (eleven) and PALB2 (three). DNA samples from anonymous cancer-free female individuals obtained from Finnish Red-Cross blood donors ( $\mathrm{N}=$ 104-299, depending on the tested mutation), originating from the same geographical region as the studied cancer cases, were used as controls. All patients had given their informed consent for acquisition of pedigree data and blood specimens for the study of cancer susceptibility gene mutations. Approval to perform the study was obtained from the Ethical Board of the Northern Ostrobothnia Health Care District and the Finnish Ministry of Social Affairs and Health.

\section{DNA extraction and mutation analysis}

Genomic DNA was extracted from blood lymphocytes using either the standard phenol-chloroform method or the Puregene D-50K purification kit (Gentra, Minneapolis, MN, USA). Mutation screening of the coding regions and exon-intron boundaries of the RNF8, UBC13 and $M M S 2$ genes was carried out by conformation sensitive gel electrophoresis (CSGE) [23], high resolution melting (HRM) analysis [24], or by direct sequencing. Samples with band shifts in CSGE or deviant melt curves in HRM were reamplified and sequenced with Li-Cor IR2 4200-S DNA Analysis system (Li-Cor, Inc., Lincoln, NE, USA) or with capillary sequencing using ABI3130xl Genetic Analyzer (Applied Biosystems, Foster City, CA, USA). For Li-Cor the Sequi Therm EXEL II DNA Sequencing Kit-LC (Epicentre Technologies, Madison, WI, USA) and for ABI the Big dye terminator kit v1.1 (Applied Biosystems, Foster City, CA, USA) were used. Chromatograms were interpreted using CodonCode Aligner v. 3.5.4 (Codon Code Corporation, Dedham, MA, USA) and with MEGA4 [25]. Oligonucleotides for CSGE, HRM and sequencing (Table 2) were designed using Primer3 software [26], based on sequence information obtained from public databases (NC_000006.11, NC_000012.11 and NC_000008.10).

\section{Statistical and bioinformatical analysis}

Carrier frequencies between patients and healthy controls were compared by using Pearson Chi-Square or Fisher's exact test in PASW Statistics (version 18 for Windows, SPSS Inc., Chicago, IL, USA), which was also used for the generation of odds ratios and confidence 
Table 2 Primers used for the screening of RNF8, UBC13 and MMS2

\begin{tabular}{|c|c|c|c|c|}
\hline Gene & Exon & Forward primer $\left(5^{\prime}-3^{\prime}\right)$ & Reverse primer $\left(5^{\prime}-3^{\prime}\right)$ & PCR fragment size (bp) \\
\hline \multirow[t]{11}{*}{ RNF8 } & 1 & GCGAGGAGACCTCTCGAATC & TCCTCTCTGCCATTCATTCA & 498 \\
\hline & 2 & TGCTGCTGGTTGATGAGAT & AAATAAAAGTCATTAGGCTTCTG & 250 \\
\hline & 3a & AAGAAGACGAAAATCATGAAGC & TAATTCATCCAAACTGAATTTCC & 294 \\
\hline & $3 b$ & CCTTGTCTITCCCCAAAGAAT & TTACTTGGCTCAAGGGCAGT & 242 \\
\hline & $3 c$ & AGTGGCCAGTACACCCTCTG & TTCACATTCATAACGGCTTCA & 240 \\
\hline & $3 d$ & GGTGACCATGTCCAGGATTC & AAGACCACTCTTGCCCTTCC & 260 \\
\hline & 4 & CAGGAGATTTTCCACCTGCT & GGTCATGTGATGCCTGTTTG & 271 \\
\hline & 5 & CAGGCATGTTTGTGGCTAAA & CCTAGCAACCCTTGCACTGT & 242 \\
\hline & 6 & CCTGTCCCATTTTGCATTTT & AAGGGGTGAGCAACTGTTC & 197 \\
\hline & 7 & GCCCTTAAGATGGGATTGTTG & TCССТTТАСТССТССССАТT & 483 \\
\hline & 8 & AGGGAAATACAGGCTCCTCA & CAAGTGACTGAGGGCTTCCT & 220 \\
\hline \multirow[t]{4}{*}{ UBC13 } & 1 & GACTTCCACTCGTGCGTGA & TCCTCAGCACCCGACTTC & 264 \\
\hline & 2 & TTGGGAGATTGGAGCTGTTC & TGGAATGCTTAAGAGAAAAAGGA & 430 \\
\hline & 3 & GTCTGTGGGAGGGAAGTGAA & CCCATAGCAAGCCATTTGT & 385 \\
\hline & 4 & ATCTITCAGCCCTGATCCAA & GAGGGGCCACTGCTITTA & 448 \\
\hline \multirow[t]{4}{*}{ MMS2 } & 1 & CCCGGCCCTCATGAACTT & GGTCCCAGGCTACGCTCT & 411 \\
\hline & 2 & AGGGGATTTGGTCTTTTTGG & CACGTGGGAAGCATCAATAA & 421 \\
\hline & 3 & GCACTTAGACATTAATATTTAAGGTA & TITGGCTTAACAAAGGTCCTC & 331 \\
\hline & 4 & TGCTTAACAAATTGGTGCCATA & GCTGCATTITCCTCCTGTT & 408 \\
\hline
\end{tabular}

intervals. All alterations were checked with NNSplice software for potential splicing effects http://www.fruitfly. org/seq_tools/splice.html.

\section{Results}

The mutation analysis of RNF8 revealed two exonic, two intronic and three 5'UTR variants. Only one of these variants was novel (not reported the NCBI SNP database, http://www.ncbi.nlm.nih.gov/SNP/). Both of the observed exonic variants of RNF8 were synonymous. In the $U B C 13$ gene, one unreported and one known intronic variant were observed, whereas no sequence alterations were observed in $M M S 2$. All observed alterations in $R N F 8$ and $U B C 13$ were assessed for possible effects on consensus splice sites, but none of them had a predicted effect on splicing. In order to evaluate possible pathogenicity of the observed changes, their frequencies were compared between cases and healthy control individuals. None of the found sequence changes, however, appeared to associate with breast cancer susceptibility (Table 3).

\section{Discussion}

RNF8, UBC13 and MMS2 have important roles in the maintenance of genomic integrity and cell-cycle checkpoint control $[9-11,19]$. Based on their involvement in DDR and importance in BRCA1-mediated DNA damage recognition it was considered possible that mutations in these genes might contribute to hereditary predisposition to breast cancer.
In the current study, the whole coding region of the RNF8, UBC13 and MMS2 genes was systematically screened for mutations in 123 breast cancer families. No deleterious sequence alterations were observed in any of the genes. Previous studies have suggested that the RNF8 gene could be novel tumor suppressor [17], but it seems that germline mutations predisposing to breast cancer in this gene do not exist or, at least, are very rare. It is of interest that another E3 ligase, RNF168, which acts together with UBC13 to amplify the RNF8dependent histone ubiquitylation has been shown to be defected in RIDDLE syndrome, which is an immunodeficiency and radiosensitivity disorder. However, it is still unclear whether RIDDLE syndrome is associated with genome instability or increased tumor incidence [12].

\section{Conclusion}

The present data suggest that mutations predisposing to breast cancer are either very rare or absent in the coding region of the RNF8, UBC13 and MMS2 genes, which could possibly point to the essentiality of their protein products in the DNA damage response and other functions maintaining genomic integrity. Although a small study like this cannot exclude the possibility of some other rare mutations in RNF8, UBC13 and MMS2 might predispose to breast cancer, based on our findings they unlikely make any sizeable contribution to cancer predisposition. To our knowledge, this is the first study reporting the mutation screening of the RNF8, UBC13 and MMS2 genes in familial breast cancer cases. 
Table 3 Observed alterations in the RNF8,UBC13 and MMS2 genes in Finnish breast cancer families

\begin{tabular}{lccccc}
\hline Gene & Nucleotide change & rs number & \multicolumn{2}{c}{ Carrier frequency } & P-value \\
(OR; 95\% Cl)
\end{tabular}

OR, Odds ratio; $\mathrm{Cl}$, confidence interval; UTR, untranslated region.

\section{Acknowledgements}

We thank Dr. Aki Mustonen and nurse Outi Kajula for their help in sample and data collection and in patient contacts. The technical assistance by Meeri Otsukka is greatly appreciated. We thank all the patients and their family members for volunteering to participate in these studies, as well as the Finnish Red Cross Blood Service for help with collection of population control blood samples. This study was financially supported by the Sigrid Jusélius Foundation, the Finnish Cancer Foundation, the Cancer Fund of Northern Finland, the Academy of Finland, the University of Oulu, and the Oulu University Hospital.

\section{Authors' contributions}

MV carried out the mutation screening and data analysis, and drafted the manuscript. RW and KP designed the study and revised the manuscript. All authors read and approved the final manuscript.

\section{Competing interests}

The authors declare that they have no competing interests.

Received: 11 April 2011 Accepted: 21 July 2011 Published: 21 July 2011

\section{References}

1. Parkin DM, Bray F, Ferlay J, Pisani P: Global cancer statistics, 2002. CA Cancer J Clin 2005, 55(2):74-108.

2. Collaborative Group on Hormonal Factors in Breast Cancer: Familial breast cancer: collaborative reanalysis of individual data from 52 epidemiological studies including 58,209 women with breast cancer and 101,986 women without the disease. Lancet 2001, 358(9291):1389-1399.

3. Antoniou AC, Easton DF: Models of genetic susceptibility to breast cancer. Oncogene 2006, 25(43):5898-5905.

4. Ripperger T, Gadzicki D, Meindl A, Schlegelberger B: Breast cancer susceptibility: current knowledge and implications for genetic counselling. Eur J Hum Genet 2009, 17(6):722-731.

5. Erkko H, Xia B, Nikkilä J, Schleutker J, Syrjäkoski K, Mannermaa A, Kallioniemi A, Pylkäs K, Karppinen SM, Rapakko K, Miron A, Sheng Q, Li G, Mattila H, Bell DW, Haber DA, Grip M, Reiman M, Jukkola-Vuorinen A, Mustonen A, Kere J, Aaltonen LA, Kosma VM, Kataja V, Soini Y, Drapkin Rl, Livingston DM, Winqvist R: A recurrent mutation in PALB2 in Finnish cancer families. Nature 2007, 446(7133):316-319.
6. Meindl A, Hellebrand H, Wiek C, Erven V, Wappenschmidt B, Niederacher D, Freund M, Lichtner P, Hartmann L, Schaal H, Ramser J, Honisch E, Kubisch C, Wichmann HE, Kast K, Deissler H, Engel C, Muller-Myhsok B, Neveling K, Kiechle M, Mathew CG, Schindler D, Schmutzler RK, Hanenberg H: Germline mutations in breast and ovarian cancer pedigrees establish RAD51C as a human cancer susceptibility gene. Nat Genet 2010, 42(5):410-414.

7. Seal S, Thompson D, Renwick A, Elliott A, Kelly P, Barfoot R, Chagtai T, Jayatilake H, Ahmed M, Spanova K, North B, McGuffog L, Evans DG, Eccles D, Breast Cancer Susceptibility Collaboration (UK), Easton DF, Stratton MR, Rahman N: Truncating mutations in the Fanconi anemia J gene BRIP1 are low-penetrance breast cancer susceptibility alleles. Nat Genet 2006, 38(11):1239-1241.

8. Al-Hakim A, Escribano-Diaz C, Landry MC, O'Donnell L, Panier S, Szilard RK, Durocher D: The ubiquitous role of ubiquitin in the DNA damage response. DNA Repair (Amst) 2010, 9(12):1229-1240.

9. Huen MS, Grant R, Manke I, Minn K, Yu X, Yaffe MB, Chen J: RNF8 transduces the DNA-damage signal via histone ubiquitylation and checkpoint protein assembly. Cell 2007, 131(5):901-914.

10. Kolas NK, Chapman JR, Nakada S, Ylänkö J, Chahwan R, Sweeney FD, Panier S, Mendez M, Wildenhain J, Thomson TM, Pelletier L, Jackson SP, Durocher D: Orchestration of the DNA-damage response by the RNF8 ubiquitin ligase. Science 2007, 318(5856):1637-1640.

11. Mailand N, Bekker-Jensen S, Faustrup H, Melander F, Bartek J, Lukas C, Lukas J: RNF8 ubiquitylates histones at DNA double-strand breaks and promotes assembly of repair proteins. Cell 2007, 131(5):887-900.

12. Stewart GS, Panier S, Townsend K, Al-Hakim AK, Kolas NK, Miller ES, Nakada S, Ylanko J, Olivarius S, Mendez M, Oldreive C, Wildenhain J, Tagliaferro A, Pelletier L, Taubenheim N, Durandy A, Byrd PJ, Stankovic T, Taylor AM, Durocher D: The RIDDLE syndrome protein mediates a ubiquitin-dependent signaling cascade at sites of DNA damage. Cell 2009, 136(3):420-434

13. Sobhian B, Shao G, Lilli DR, Culhane AC, Moreau LA, Xia B, Livingston DM, Greenberg RA: RAP80 targets BRCA1 to specific ubiquitin structures at DNA damage sites. Science 2007, 316(5828):1198-1202.

14. Shao G, Patterson-Fortin J, Messick TE, Feng D, Shanbhag N, Wang Y, Greenberg RA: MERIT40 controls BRCA1-Rap80 complex integrity and recruitment to DNA double-strand breaks. Genes Dev 2009, 23(6):740-754.

15. Shao G, Lilli DR, Patterson-Fortin J, Coleman KA, Morrissey DE, Greenberg RA: The Rap80-BRCC36 de-ubiquitinating enzyme complex 
antagonizes RNF8-Ubc13-dependent ubiquitination events at DNA double strand breaks. Proc Natl Acad Sci USA 2009, 106(9):3166-3171.

16. Wang B, Elledge SJ: Ubc13/Rnf8 ubiquitin ligases control foci formation of the Rap80/Abraxas/Brca1/Brcc36 complex in response to DNA damage. Proc Natl Acad Sci USA 2007, 104(52):20759-20763.

17. Li L, Halaby MJ, Hakem A, Cardoso R, El Ghamrasni S, Harding S, Chan N, Bristow R, Sanchez O, Durocher D, Hakem R: Rnf8 deficiency impairs class switch recombination, spermatogenesis, and genomic integrity and predisposes for cancer. J Exp Med 2010, 207(5):983-997.

18. Hofmann RM, Pickart CM: Noncanonical MMS2-encoded ubiquitinconjugating enzyme functions in assembly of novel polyubiquitin chains for DNA repair. Cell 1999, 96(5):645-653.

19. Andersen PL, Zhou H, Pastushok L, Moraes T, McKenna S, Ziola B, Ellison MJ, Dixit VM, Xiao W: Distinct regulation of Ubc13 functions by the two ubiquitin-conjugating enzyme variants Mms2 and Uev1A. J Cell Biol 2005, 170(5):745-755.

20. Huen MS, Huang J, Yuan J, Yamamoto M, Akira S, Ashley C, Xiao W, Chen J: Noncanonical E2 variant-independent function of UBC13 in promoting checkpoint protein assembly. Mol Cell Biol 2008, 28(19):6104-6112.

21. Nikkilä J, Coleman KA, Morrissey D, Pylkäs K, Erkko H, Messick TE, Karppinen SM, Amelina A, Winqvist R, Greenberg RA: Familial breast cancer screening reveals an alteration in the RAP80 UIM domain that impairs DNA damage response function. Oncogene 2009, 28(16):1843-1852.

22. Antoniou AC, Wang $X$, Fredericksen ZS, McGuffog L, Tarrell R, Sinilnikova OM, Healey S, Morrison J, Kartsonaki C, Lesnick T, Ghoussaini M, Barrowdale D, EMBRACE, Peock S, Cook M, Oliver C, Frost D, Eccles D, Evans DG, Eeles R, lzatt L, Chu C, Douglas F, Paterson J, Stoppa-Lyonnet D, Houdayer C, Mazoyer S, Giraud S, Lasset C, Remenieras A, et al. : A locus on 19 p13 modifies risk of breast cancer in BRCA1 mutation carriers and is associated with hormone receptor-negative breast cancer in the general population. Nat Genet 2010, 42(10):885-892.

23. Körkkö J, Annunen S, Pihlajamaa T, Prockop DJ, Ala-Kokko L: Conformation sensitive gel electrophoresis for simple and accurate detection of mutations: comparison with denaturing gradient gel electrophoresis and nucleotide sequencing. Proc Natl Acad Sci USA 1998, 95(4):1681-1685.

24. Wittwer CT: High-resolution DNA melting analysis: advancements and limitations. Hum Mutat 2009, 30(6):857-859.

25. Kumar S, Nei M, Dudley J, Tamura K: MEGA: a biologist-centric software for evolutionary analysis of DNA and protein sequences. Brief Bioinform 2008, 9(4):299-306.

26. Rozen S, Skaletsky H: Primer3 on the WWW for general users and for biologist programmers. Methods Mol Biol 2000, 132:365-386.

27. Novak DJ, Sabbaghian N, Maillet P, Chappuis PO, Foulkes WD Tischkowitz M: Analysis of the genes coding for the BRCA1-interacting proteins, RAP80 and Abraxas (CCDC98), in high-risk, non-BRCA1/2, multiethnic breast cancer cases. Breast Cancer Res Treat 2009, 117(2):453-459.

28. Akbari MR, Ghadirian P, Robidoux A, Foumani $M$, Sun $Y$, Royer R, Zandvakili I, Lynch H, Narod SA: Germline RAP80 mutations and susceptibility to breast cancer. Breast Cancer Res Treat 2009, 113(2):377-381.

29. Osorio A, Barroso A, García MJ, Martínez-Delgado B, Urioste M, Benítez J: Evaluation of the BRCA1 interacting genes RAP80 and CCDC98 in familial breast cancer susceptibility. Breast Cancer Res Treat 2009, 113(2):371-6

30. Solyom S, Patterson-Fortin J, Pylkäs K, Greenberg RA, Winqvist R: Mutation screening of the MERIT40 gene encoding a novel BRCA1 and RAP80 interacting protein in breast cancer families. Breast Cancer Res Treat 2010, 120(1):165-168.

\section{Pre-publication history}

The pre-publication history for this paper can be accessed here: http://www.biomedcentral.com/1471-2350/12/98/prepub

doi:10.1186/1471-2350-12-98

Cite this article as: Vuorela et al:: Mutation screening of the RNF8, UBC13 and MMS2 genes in Northern Finnish breast cancer families. BMC Medical Genetics 2011 12:98

\section{Submit your next manuscript to BioMed Central and take full advantage of:}

- Convenient online submission

- Thorough peer review

- No space constraints or color figure charges

- Immediate publication on acceptance

- Inclusion in PubMed, CAS, Scopus and Google Scholar

- Research which is freely available for redistribution

Submit your manuscript at www.biomedcentral.com/submit
Biomed Central 